\title{
MEASURING THE EFFECT OF PERFORMANCE APPRAISAL ON JOB SATISFACTION
}

\author{
Gurleen Kaur \\ Research Scholar, ICFAI Business School, The ICFAI University Dehradun, India \\ Dr. Deepti Kiran* \\ Assistant Professor, ICFAI Business School, The ICFAI University Dehradun, India \\ *Corresponding Author
}

\begin{abstract}
Performance is not a choice but a must do practice for organizations. The current study is an effort to study the performance evaluation practices of pharmaceutical companies of Punjab. The variables of performance measure have been identified through literature and were grouped into various factors through factor analysis. The impact of performance appraisal practices has been measured on the job satisfaction of lower and middle level employees through regression analysis. The results suggest a strong association between performance appraisal and job satisfaction. The results also highlight that fair the system of appraisal, more is the job satisfaction which improves the productivity of employees.
\end{abstract}

Key words: Performance appraisal, pharmaceutical, Punjab, job satisfaction

Cite this Article: Gurleen Kaur and Deepti Kiran, Measuring the Effect of Performance Appraisal on Job Satisfaction, International Journal of Management, 11(12), 2020, pp 2911-2918.

http://iaeme.com/Home/issue/IJM?Volume=11\&Issue=12

\section{INTRODUCTION}

Performance evaluation is to access an employee's present and past performance with reference to their standard. Appraisal of performance is a vital activity of human resource department of any company and it's one of the most complex processes. It becomes more complicated if the performance standards are not objective and not communicated clearly to the employees (rate). Performance appraisal (PA) is a controlled formal communication amid an assistant and manager. It, by and large is a type of a periodic meeting (yearly/half yearly), where the job related performance of the subordinate is checked and discussed. It is done to identify the weaknesses and strengths along with opportunities for overall development.

Performance Appraisal is a tool to measure the gap in the actual performance of the employee and the expected performance by the management. It allows the companies to know the effectiveness of an employee related to job requirements for which he is hired. The 
appraisals decides that what the employee has done/doing for the organization and what they deserve in return in terms of appreciation for their worth and dedication towards his job.

Generally people take performance appraisal as appraisal tools. Performance assessment presumes that the employees are aware of the performance criteria and received the opinions required to eliminate the performance deficiencies. The aim is to develop the employee's, and, thus the organization (Garry Dessler 1999). Best groups a formal assessment method as they contemplate performance appraisal as essential for organization's success.

The idea behind performance appraisal process is to make employees future centric rather than past oriented. Performance assessment is vital for both the employee and the organization. The employees on the basis of appraisals can alter the work behavior and enhance their efficiency which further increases the probability of receiving rise in compensation and/or recognition. It's a continuous process which regularly offers inputs on decisions like increments, promotions, transfers, training, bonus etc. The organizations find it important, because of its wide use in making decisions on promotion, transfer, rewards etc. and to give feedback to individuals which help in their personal and career progression which further assures organizational effectiveness (Kane and Lawler 1979).

The Indian Pharmaceutical Industry starting from scratch in 1970s became one of the major and extremely progressive industry of the world. It generated employment to billions and makes sure the availability of the necessary medicines to Indians and foreigners at reasonable prices. A number of manufacturing plants have been approved by US FDA. Indian medicinal industry sells around $85 \%$ formulations produced in own country in the national market, whereas $60 \%$ of India's wholesale drug production is exported. A pharmaceutical industry requires skilled and efficient workers as its highly technology oriented and there believe in zero tolerance in terms of quality of products and services. It is the human resource that plays a major role and the most important tool to ensure skilled and efficient employee is performance appraisal.

\section{LITERATURE REVIEW}

The researches in past analyzed the influence of the social context of performance appraisals on employee reactions towards such appraisals. A few study related to the appraisal and it direct or indirect effect on job satisfaction have been briefed here.

Poon (2004), studied the response of workers to different characteristics of the appraisal procedure. The study found significantly positive connection between performance appraisal with the job satisfaction among employees in multinational companies in Malaysia.

Bhatti and Qureshi (2007) found an affirmative relationship amid performance appraisal with job satisfaction which increases employee efficiency. How (2011) also found an affirmative association amid performance appraisal and job contentment amongst employees in domestic companies of Malaysia. It means satisfied employees contribute towards accomplishments of organizational objectives in effective manner.

Bekele, Shigutu and Tensay, (2011) studied employees views on the prevailing performance evaluation system in the organization and its association with intentions to quit, commitment towards goals of organization and work performance. The study found that the employees with a positive view on performance assessment system demonstrated superior performance, greater commitment \& have lesser turnover intentions.

Shrivastava and Rai (2012), considered performance evaluation practices in various Indian banks and found performance appraisal as an important factor in improving organization's ability. It also suggested that though every bank considers performance assessment as a crucial activity in order to increase organizational ability but each bank has its own way of measuring employee performance. Bhatia and Jain (2012), examined the perception of employees towards 
prevailing performance appraisal procedures in Telecom companies and its association with organizational effectiveness in Bhopal city of India. The study found that the employees are dissatisfied with the system as it is not motivational or reward centric and no post appraisal interview was conducted.

Mahajan and Raheja (2013), studied the association of job satisfaction with performance appraisal process and fairness of the system. The study found a positive association amid employee satisfactions with performance assessment system and fairness of the system.

Marawar (2013) studied the performance evaluation system in two construction based companies of Pune and proposed a different evaluation system which may remove the shortcomings of the prevailing system.

Deepa and Kuppusamy (2013) assessed the performance evaluation methods followed in oil and refinery industries in Coimbatore city and analyzed the employee's views on the existing performance appraisal system. The study revealed that if employee's have positive views towards performance assessment system, their potential capabilities are improved. Mondy \& Mondy, (2014) defined performance appraisal as a process which evaluates employee's performance and in the meantime supervisors may improve their skills and the organization's performance simultaneously.

Rao and Rani (2014) examined the grading mistakes in the current appraisal process in the banks with focus on employee satisfaction. The study was done in Chennai city. The study found that rating mistakes significantly affect the performance appraisal which in turn influences employee satisfaction.

Agyare et. al. (2016) investigated the impacts of performance appraisal on the jobsatisfaction and commitment of employees of Microfinance organizations in Ghana. The study using Regression Analysis and correlations discovered that the job satisfaction of employees has positive and significant fairness of the appraisal process, connecting appraisals with advancement in career, provides role clarity and feedback about their performance.

In the light of above discussion this study attempts to study the impact of performance appraisal process on the job satisfaction of employees of pharmaceutical companies in Punjab.

\section{RESEARCH DESIGN}

\subsection{Variables for Study}

Job satisfaction is a vital subject for all organization nowadays. The reason for it is that satisfied employees perform better. Job satisfaction is measured by the variables such as salary, nature of job, management, advancement, co-worker and work atmosphere. It indicates about employees' perception about their job and demonstrates the level to which employees are satisfied with their jobs. The contentment level of the workers is also shown by growth in organization's productivity. A few statements considered for the job satisfaction of employees are:

- My organization believes in ability utilization and achievements.

- There are enough activities which bring out my creativity and help in career advancement.

- I get authority, independence in my area within the company policy.

- The compensation and co-workers are descent.

- I get responsibility as per my skills and I am recognized if I perform well.

- My job gives me social status and a sense of security.

- My supervisor believes in human relations and helps me technically as well. 
- The working conditions are appropriate.

The statements related to performance analysis are:

- The organization evaluates the performance on regular basis.

- The procedure of performance assessment is transparent.

- The process of performance assessment is fair.

- The goals of performance assessment are briefed before the commencement of the evaluation period.

- Performance evaluation goals are mutually decided.

- The performance management process helps in setting and achieve significant goals.

- The weights set for each activity to be performed in the stated period by performance management system (pms) are agreeable.

- The process of performance appraisal is unbiased.

- The process of performance appraisal gives enough scope to measure the goals set and achieved.

- The performance appraisal methods are modified from time to time as per requirements.

- The performance appraisal methods are flexible enough to accommodate the modifications if required.

- The performance appraisal method is efficient enough to measure the ability utilization.

- The performance appraisal method takes care of the biasness of rater.

- The performance appraisal method takes care of the limitations of rater.

- The performance appraisal method takes care of the reasons between performance expectations and actual performance.

- The PMS applied in organization generates a participative atmosphere.

- The promotions are stringently on the basis of PMS.

- The increments are strictly based on PMS.

- The job performance of employees has shown improvement due to the existing PMS.

- The disagreement regarding the appraisal decisions can be freely expressed to the appraiser.

- The performance assessment gives positive criticism in a friendly way.

- The performance assessment increases motivation to perform.

- The existing Performance Management System is overall satisfactory.

\subsection{Methodology}

Sample: The current study collected responses from 484 respondents working in three pharmaceutical companies in Punjab. Originally 500 questionnaires were circulated but finally 484 responses were complete in all the aspects out of which 355 were male and 129 were female respondents. Data was collected from employees on a random basis. 
Instrument: The present study is based on the primary data collected through a close ended questionnaire which had 35 items. Among them four items measured demographics, twenty three items measured employee appraisal system used in the company and eight items measured employee's satisfaction with their job in the selected company. The questions were adopted from past researches. Apart from demographics, the items were marked on five point Likert scale of " 1 to 5", where 1 denoted strongly disagree or strongly dissatisfied and 5 denoted strongly agree or strongly satisfied for employee performance assessment method and job related employee satisfaction respectively.

\section{RELIABILITY ANALYSIS}

\subsection{The Reliability Analysis of the Questionnaire was Conducted through Cronbach Alpha}

Table 1: Reliability Statistics

\begin{tabular}{|c|c|c|}
\hline Variable & No. of items & Cronbach's Alpha \\
\hline PA & 23 & 0.79 \\
\hline JS & 8 & 0.83 \\
\hline
\end{tabular}

The value is sufficiently large to believe the reliability of the questionnaire.

A factor analysis of variables of performance appraisal was conducted to group the variables of performance appraisal as they are more in number. When the exploratory factor analysis was conducted, it was found that they group into seven categories.

\begin{tabular}{|l|l|l|}
\hline \multicolumn{2}{|c|}{ Table 2: KMO and Bartlett's Test } \\
\hline Kaiser-Meyer-Olkin Value. & .767 \\
\hline Bartlett's Test of Sphericity & Approx. Chi-Square & 5399.035 \\
\cline { 2 - 3 } & Sig. & .000 \\
\hline
\end{tabular}

Table 3: Total Variance Explained

\begin{tabular}{|c|c|c|c|c|c|c|c|c|c|}
\hline \multirow{2}{*}{$\begin{array}{c}\text { Componen } \\
\mathbf{t}\end{array}$} & \multicolumn{3}{|c|}{ Initial Eigenvalues } & \multicolumn{4}{c|}{ Extraction Sums of Squared Loadings } & \multicolumn{3}{c|}{$\begin{array}{c}\text { Rotation Sums of Squared } \\
\text { Loadings }\end{array}$} \\
\cline { 2 - 11 } & Total & $\begin{array}{c}\text { \% of } \\
\text { Variance }\end{array}$ & $\begin{array}{c}\text { Cumulativ } \\
\mathbf{e} \%\end{array}$ & Total & \% of Variance & $\begin{array}{c}\text { Cumulative } \\
\text { \% }\end{array}$ & Total & $\begin{array}{c}\text { \% of } \\
\text { Variance }\end{array}$ & $\begin{array}{c}\text { Cumula } \\
\text { tive \% }\end{array}$ \\
\hline 1 & 3.338 & 14.514 & 14.514 & 3.338 & 14.514 & 14.514 & 2.871 & 12.482 & 12.482 \\
\hline 2 & 2.827 & 12.293 & 26.807 & 2.827 & 12.293 & 26.807 & 2.103 & 11.142 & 23.624 \\
\hline 3 & 2.557 & 11.118 & 37.925 & 2.557 & 11.118 & 37.925 & 2.069 & 10.997 & 34.621 \\
\hline 4 & 1.995 & 10.675 & 48.600 & 1.995 & 10.675 & 48.600 & 2.052 & 9.920 & 44.541 \\
\hline 5 & 1.780 & 9.739 & 58.139 & 1.780 & 9.739 & 58.139 & 2.025 & 9.803 & 54.344 \\
\hline 6 & 1.394 & 7.061 & 65.200 & 1.394 & 7.061 & 65.200 & 1.924 & 8.467 & 62.811 \\
\hline 7 & 1.383 & 6.003 & 71.203 & 1.383 & 6.003 & 71.203 & 1.678 & 8.392 & 71.203 \\
\hline
\end{tabular}

Table 4: Rotated Component Matrix

\begin{tabular}{|l|c|c|c|c|c|c|c|}
\hline & $\mathbf{1}$ & $\mathbf{2}$ & $\mathbf{3}$ & $\mathbf{4}$ & $\mathbf{5}$ & $\mathbf{6}$ & $\mathbf{7}$ \\
\hline VAR00001 & & & & & & .804 & \\
\hline VAR00002 & & & & & & .841 & \\
\hline VAR00003 & & & & & & .648 & \\
\hline VAR00004 & & -.676 & & & & & \\
\hline VAR00005 & & & .442 & & & & \\
\hline VAR00006 & & & .734 & & & & \\
\hline VAR00007 & & -.784 & & & & & \\
\hline VAR00008 & .825 & & & & & & \\
\hline VAR00009 & & & .876 & & & & \\
\hline VAR00010 & -.608 & & & & & & \\
\hline
\end{tabular}


Measuring the Effect of Performance Appraisal on Job Satisfaction

\begin{tabular}{|l|l|l|l|l|l|l|l|}
\hline VAR00011 & & & & .781 & & & \\
\hline VAR00012 & & & -.614 & & & & \\
\hline VAR00013 & & & & .676 & & & \\
\hline VAR00014 & & & & .546 & & & \\
\hline VAR00015 & .491 & & & & & & \\
\hline VAR00016 & -.445 & & & & & & \\
\hline VAR00017 & & & & & & & .823 \\
\hline VAR00018 & & & & & & & .781 \\
\hline VAR00019 & & & & & .498 & & \\
\hline VAR00020 & & & & .599 & & & \\
\hline VAR00021 & & & & & .804 & & \\
\hline VAR00022 & & & & & -.589 & & \\
\hline VAR00023 & -.508 & & & & & & \\
\hline
\end{tabular}

On the basis of the grouping the groups are named as:

Table 5: Names of Factors

\begin{tabular}{|l|c|c|c|c|c|c|}
\hline $\begin{array}{c}\text { 1-Process of } \\
\text { PA }\end{array}$ & $\begin{array}{c}\text { 2-Fairness of } \\
\text { PA }\end{array}$ & $\begin{array}{c}\text { 3-Goals } \\
\text { of PA }\end{array}$ & $\begin{array}{c}\text { 4-Characteristics of } \\
\text { Rater }\end{array}$ & $\begin{array}{c}\text { 5-Reasons of } \\
\text { PA }\end{array}$ & $\begin{array}{c}\text { 6-Characteristics of } \\
\text { PA }\end{array}$ & $\begin{array}{c}\text { 7-Outcomes of } \\
\text { PA }\end{array}$ \\
\hline Variable 8 & Variable 4 & Variable 5 & Variable 11 & Variable 19 & Variable 1 & Variable 17 \\
\hline Variable 10 & Variable 7 & Variable 6 & Variable 13 & Variable 21 & Variable 2 & Variable 18 \\
\hline Variable 15 & & Variable 9 & Variable 14 & Variable 22 & Variable 3 & \\
\hline Variable 16 & & Variable 12 & Variable 20 & & & \\
\hline Variable 23 & & & & & & \\
\hline
\end{tabular}

A regression analysis has been conducted to see the influence of performance assessment system on the job satisfaction level of employees. Here the factors of performance appraisal system are independent variables and job satisfaction is dependent variable. The model used for study is:

$$
\mathrm{Y}=\mathrm{a}+\mathrm{b}_{1} \mathrm{X}_{1}+\mathrm{b}_{2} \mathrm{X}_{2}+\mathrm{b}_{3} \mathrm{X}_{3}+\mathrm{b}_{4} \mathrm{X}_{4}+\mathrm{b}_{5} \mathrm{X}_{5}+\mathrm{b}_{6} \mathrm{X}_{6}+\mathrm{b}_{7} \mathrm{X}_{7}+\mathrm{e}
$$

Where $\mathrm{Y}$ is job satisfaction and $\mathrm{X} 1$ is process of PA; $\mathrm{X} 2$ is Fairness of PA; $\mathrm{X} 3$ is goals of $\mathrm{PA}$; X4 is characteristics of rater, $\mathrm{X} 5$ is Reasons of PA; X6 is Characteristics of PA; X7 is outcomes of PA and e is error term. The $b$ are the coefficients to measure the sensitivity of job satisfaction towards the particular factor.

Table 6: Model

\begin{tabular}{|c|c|c|c|c|c|c|c|}
\hline \multirow[b]{2}{*}{ Model } & \multirow[b]{2}{*}{$\mathbf{R}$} & \multirow[b]{2}{*}{$\mathbf{R}^{2}$} & \multirow[b]{2}{*}{$\operatorname{Adj} R^{2}$} & \multirow{2}{*}{$\begin{array}{c}\text { Std. Error } \\
\text { of the } \\
\text { Estimate }\end{array}$} & & & \multirow[b]{2}{*}{ p-value } \\
\hline & & & & & $\mathbf{R}^{2}$ Change & $\begin{array}{c}\text { F } \\
\text { Change }\end{array}$ & \\
\hline 1 & $.843^{\mathrm{a}}$ & .711 & .707 & .80640 & .711 & 146.355 & .000 \\
\hline
\end{tabular}

Table 7: Regression Coefficients

\begin{tabular}{|c|c|c|c|c|}
\hline \multirow[b]{2}{*}{ Model } & \multicolumn{2}{|c|}{ Unstandardized Coefficients } & \multirow[b]{2}{*}{$\mathbf{t}$} & \multirow[b]{2}{*}{ Sig. } \\
\hline & B & Std. Error & & \\
\hline (Constant) & 3.248 & .037 & 88.610 & .000 \\
\hline REGR factor score 1 & .108 & .037 & 2.949 & .003 \\
\hline REGR factor score 2 & .133 & .037 & 3.615 & .000 \\
\hline REGR factor score 3 & .030 & .037 & .809 & .419 \\
\hline REGR factor score 4 & -.107 & .037 & -2.924 & .004 \\
\hline REGR factor score 5 & -.171 & .037 & -4.669 & .000 \\
\hline REGR factor score 6 & 1.196 & .037 & 32.600 & .000 \\
\hline REGR factor score 7 & .208 & .037 & 5.675 & .000 \\
\hline
\end{tabular}


The regression analysis found that the factors achieved through factor analysis are appropriate as the $\mathrm{F}$ value which indicates model fit is significant at 1 percent level of significance. The value of adjusted $\mathrm{R}$ square is also 70.7 percent which suggests that the independent variables are able to explain around 7 percent of variation in job satisfaction.

The results of regression coefficient table found the process of performance appraisal, fairness of performance appraisal, characteristics of rater, reasons, characteristics and outcomes of performance appraisal have significant relationship with job satisfaction. However the coefficient of characteristics of rater and reasons of performance appraisal turned out to be negative which suggests that if the reasons of PA are not clear or if the rater has limitations, the job satisfaction will be not there.

\section{CONCLUSION}

The analysis found a significant association amid employee performance, appraisal system and job satisfaction. The probable reason could be that the business nowadays practices the policies in a fair manner due to the strict labour laws. It endorses that performance evaluation system in practice should be fair and transparent in order to the employees satisfied. The results of the study are in line with Khan (2007) but dissimilar to that of Bricker (1992) which specified that employees were discontented with the performance appraisal systems embraced by their organizations. However numerous researchers confirmed that the satisfied employees are the key to better individual and/or organizational performance (Schneider, Hanges, Smith, and Salvaggio 2003; Ostroff, 1992; Schneider et al. 2003).

\section{REFERENCES}

[1] Agyare, R., Yuhui, G., Mensah, Aidoo, Z. and L. Ansah, I. O. (2016). The Impacts of Performance Appraisal on Employees' Job Satisfaction and Organizational Commitment: A Case of Microfinance Institutions in Ghana. International Journal of Business and Management 11(9):281

[2] Bekele, A. Z., Shigutu, A. D. and Tensay, A. T. (2011), The Effect of Employees' Perception of Performance Appraisal on Their Work Outcomes. International Journal of Management and Commerce Innovation, 2(1), 136-173.

[3] Bhatia, K. and Jain, P. (2012), A study of performance appraisal and organizational effectiveness in terms of individual and organizational basis. A comparative study of BSNL and AIRTEL, International Journal on Arts, Management and Humanities 1(1): 63-72.

[4] Deepa, E. and Kuppusamy, S. (2011), Impact of Performance Appraisal System on Job Satisfaction, Employee Engagement, Organizational Citizenship Behavior and Productivity, Indian Journal of Applied Research 4(2):4-6.

[5] Khan. A (2007) Performance Appraisal's Relation with Productivity and Job Satisfaction Journal of Managerial Sciences 1 (2):100-114

[6] Mahajan, S. and, Saloni Raheja, S. (2014) Examine Relationship between Employees Satisfaction on Performance Appraisal System with Fairness of the System. Asian J. Management 5(1),49-54.

[7] Marawar, S. (2013), Performance Appraisal System to Improve Construction Productivity, International Journal of Scientific and Research Publications, 3 (11), 1-8.

[8] Ostroff, C. (1992).The relationship between satisfaction, attitudes, and performance: An organizational Level Analysis. Journal of Applied Psychology, 77, 963-974.

[9] Poon, J. M. L. (2004). Effects of performance appraisal politics on job satisfaction and turnover intention. Personnel Review, 33(3):322-334. 
[10] Prendergast, C., \& Topel, R. (1996). Favoritism in organizations. Journal of Political Economy, 104(5):958-978.

[11] Schneider, B., Hanges, P. J., Smith, D. B., \& Salvaggio, A. N. (2003). Which comes first: Employee attitudes or organizational financial and market performance? Journal of Applied Psychology, 88, 836-851.

[12] Shrivastava, P. and Usha Kiran Rai, U. K. (2012), Performance Appraisal Practices In Indian Banks, Integral Review - A Journal of Management, 5 (2) 46-52.

[13] Thurston, P.W.Jr. (2001). Clarifying the structure of Justice using fairness perceptions of performance appraisal practices. Unpublished PhD Dissertation, Albany, NY.

[14] Vijaya Rao, M. S. and Sheela Rani, S. (2014), A Study on Performance Appraisal Errors of Public Sector Bank Managers in Chennai. Proceedings of the Second International Conference on Global Business, Economics, Finance and Social Sciences (GB14Chennai Conference) ISBN: 978-1-941505-14-4 Chennai, India 11-13 July 2014

[15] https://www.projects4mba.com/best-questionnaire-for-performance-management-system$\mathrm{pms} / 351 /$ 